CZASOPISMO INŻYNIERII LADOWEJ, ŚRODOWISKA I ARCHITEKTURY JOURNAL OF CIVIL ENGINEERING, ENVIRONMENT AND ARCHITECTURE

JCEEA, t. XXXII, z. 62 (3/I/15), lipiec-wrzesień 2015, s. 413-427

Piotr STRZELCZYK
Zygmunt SZCZERBA $^{2}$
Agnieszka WOŹNIAK $^{3}$

\title{
MODELOWANIE PIONOWEGO PROFILU PRĘDKOŚCI WIATRU W TUNELU AERODYNAMICZNYM
}

\begin{abstract}
Elektrownie wiatrowe mają coraz większy udział w produkcji energii elektrycznej w Polsce [8]. Rośnie więc znaczenie elektrowni wiatrowych. Uruchamiane są nowe farmy wiatrowe i istotnego znaczenia nabiera konstrukcja turbin wiatrowych i jakość produkowanego przez nie prądu elektrycznego. Coraz ważniejsze staje się ściślejsze określenie czynników wpływających na konwersję energii wiatru na energię elektryczną $i$ tym samym na system energetyczny. Jednym z najważniejszych warunków jakie muszą być spełnione aby inwestycja budowy przydomowej elektrowni wiatrowej była opłacalna jest jej lokalizacja. Prędkość wiatru rośnie wraz z wysokością. Na produkcję energii elektrycznej wydaje się mieć wpływ również wysokość osi wirnika. Rozsądnym wydaje się uwzględnienie w geometrii wirnika wpływ pionowego profilu prędkości wiatru. Należy podkreślić, że pionowy gradient prędkości ma większy wpływ na charakterystyki aerodynamiczne turbiny, w przypadku jednostek małych, mogących mieć zastosowanie w gospodarstwach domowych, czy w przypadku pracy z siecią rozproszoną. Dzieje się tak, gdyż wieża jest stosunkowo niska więc wpływ warstwy przyziemnej będzie bardziej istotny niż w przypadku turbin dużych. W tym artykule opisano próbę eksperymentalnego odtworzenia pionowego profilu wiatru w warunkach laboratoryjnych.
\end{abstract}

Słowa kluczowe: turbina wiatrowa, pionowy profil prędkości wiatru, geometria wirnika, tunel aerodynamiczny

\footnotetext{
${ }^{1}$ Piotr Strzelczyk, Politechnika Rzeszowska, Al. Powstańców Warszawy 8, 35-959 Rzeszów, tel. 17 8651608, piotstrz@ prz.edu.pl

2 Zygmunt Szczerba, Politechnika Rzeszowska, Al. Powstańców Warszawy 8, 35-959 Rzeszów, tel. 17 8651502,zygszcze@ prz.edu.pl

${ }^{3}$ Autor do korespondencji: Agnieszka Woźniak, Państwowa Wyższa Szkoła Zawodowa w Krośnie, ul. Rynek 1, 38-400 Krosno, tel. 13 4375500, agnieszka.wozniak@pwsz.krosno.pl
} 


\section{Wprowadzenie}

Podstawową zaletą wiatru jest jego ogólna dostępność. Niekorzystną cechą wiatru jako źródła energii jest duże i nierównomierny rozkład przestrzenny oraz zmienność w czasie, a także mała gęstość energii.

Energia wiatru może być wykorzystana w elektrowni wiatrowej w zakresie prędkości od ok.2,5 $\div 4 \mathrm{~m} / \mathrm{s}$ do ok. $20-25 \mathrm{~m} / \mathrm{s}$, poniżej dolnego zakresu wykorzystanie jest możliwe, ale nie ma uzasadnienia ekonomicznego, natomiast powyżej górnej granicy ze względów bezpieczeństwa konstrukcji wyłącza się elektrownie wiatrową z pracy.

Tarcie pomiędzy powierzchnią terenu a poruszającym się powietrzem wytwarza przestrzenny profil prędkości wiatru, w którym średnioroczne prędkości wiatru rosną wraz z wysokością. Jest on silnie związany z rodzajem terenu.

Rozkład prędkości średniej w obszarze warstwy przyziemnej można zapisać za pomocą potęgowej funkcji w postaci [7]:

$$
v(h)=v_{m}\left(\frac{h}{10}\right)^{\alpha}
$$

gdzie:

$v_{m}$-prędkość wiatru na wysokości $h=10 \mathrm{~m}[\mathrm{~m} / \mathrm{s}]$

$h$-wysokość nad powierzchnią terenu [m]

$\alpha$-współczynnik zależny od rodzaju terenu.

Pionowy profil prędkości może być przedstawiony w postaci funkcji logarytmicznej $[2,4]$ odzwierciedlającej profil prędkości w turbulentnej warstwie przyściennej nad chropowatą płaską płytą:

$$
\frac{v(h)}{v(10)}=\ln \left(\frac{h}{z_{0}}\right) / \ln \left(\frac{10}{z_{0}}\right)
$$

$\mathrm{z}_{0}$ - parametr szorstkości, zależny od rodzaju terenu wyrażony w [m]

$\mathrm{v}(10)$ - średnioroczna prędkość wiatru mierzona na wysokości $10 \mathrm{~m}$ nad poziomem gruntu.

Dla celów energetyki wiatrowej, wykorzystuje się sześciostopniową skalę szorstkości terenu, która została przedstawiona w tab. 1.

Na Rys. 1 przedstawiono wykres prędkości wiatru w zależności od wysokości $h$ przy różnych współczynnikach chropowatości $\alpha$, wg zależności potęgowej (1). Do obliczeń przyjęto prędkość średnioroczną $8 \mathrm{~m} / \mathrm{s}$ mierzoną na wysokości $10 \mathrm{~m}$. 
Tabela.1. Klasyfikacja szorstkości terenu, opracowano na podstawie [7]

Tabele.1. Classification roughness, on the basis of [7]

\begin{tabular}{|c|c|c|c|}
\hline $\begin{array}{c}\text { Klasa } \\
\text { szorstkości }\end{array}$ & $\begin{array}{c}\text { Współczynnik } \alpha \\
\text { dla czasu uśred- } \\
\text { niania 10 min }\end{array}$ & $\begin{array}{c}\text { Współczynnik } \\
\alpha \text { dla czasu } \\
\text { uśredniania 1h }\end{array}$ & Opis terenu \\
\hline 0 & 0,130 & 0,150 & $\begin{array}{c}\text { Teren płaski otwarty, na którym wyso- } \\
\text { kość nierówności jest mniejsza od 0.5 m }\end{array}$ \\
\hline 1 & 0,140 & 0,165 & $\begin{array}{c}\text { Teren płaski otwarty lub nieznacznie } \\
\text { pofalowany. Pojedyncze zabudowania } \\
\text { lub drzewa }\end{array}$ \\
\hline 2 & 0,155 & 0,190 & $\begin{array}{c}\text { Teren płaski lub pofalowany z otwartymi } \\
\text { przestrzeniami. Grupy drzew lub niska } \\
\text { zabudowa }\end{array}$ \\
\hline 3 & 0,170 & 0,200 & $\begin{array}{c}\text { Tereny zalesione, przedmieścia więk- } \\
\text { szych miast oraz małe miasta, tereny } \\
\text { przemysłowe luźno zabudowane }\end{array}$ \\
\hline 4 & 0,200 & 0,270 & $\begin{array}{c}\text { Teren z licznymi przeszkodami zlokali- } \\
\text { zowanymi w niedużej odległości tj. sku- } \\
\text { piska drzew, budynków w odległości } \\
\text { min. 300 [m] od miejsca obserwacji }\end{array}$ \\
\hline 5 & 0,245 & 0,350 & $\begin{array}{c}\text { Teren z licznymi dużymi przeszkodami } \\
\text { położonych blisko siebie, obszary leśne, } \\
\text { centra dużych miast }\end{array}$ \\
\hline
\end{tabular}

\section{Eksperymentalne wyznaczanie profilu prędkości wiatru w tunelu aerodynamicznym - przegląd literatury}

Większość tunelach aerodynamicznych dedykowanych do zastosowań lotniczych celem nadrzędnym jest utrzymanie niskiego poziomu turbulencji, przy możliwie wyrównanym profilu prędkości w przestrzeni pomiarowej.

$\mathrm{W}$ przypadku badań modelowych turbin wiatrowych czy w inżynierii wiatrowej pożądane jest odtworzenie profilu prędkości możliwie zbliżonego do występującego w terenie.

Oznacza to, że zarówno prędkość średnia wiatru, jak i intensywność turbulencji wiatru powinna być zbliżona do atmosferycznej warstwy przyziemnej. Wpływ terenu zurbanizowanego symulowano w pracach $[1,2,6]$ przy pomocy pięciu ćwierć-eliptycznych wież, a szorstkość terenu modelowano przy pomocy sześcianów rozstawionych na dwa różne sposoby (Rys.2).

Podobną symulację przeprowadzono w pracy [3]. Celem jej było w miarę dokładne odtworzenie warstwy przyziemnej terenów miejskich i podmiejskich. Do jej modelowania wykorzystano 4 trójkątne wieże, dwa rodzaje barier oraz różne rodzaje chropowatości podłoża.

W badanach prezentowanych w pracach $[1,13]$ również zajmowano się odtworzeniem profili prędkości wiatru. Przedmiotem badań był wpływ roślinności 
znajdującej się nad brzegiem jeziora na naprężenia styczne działające na jego taflę.

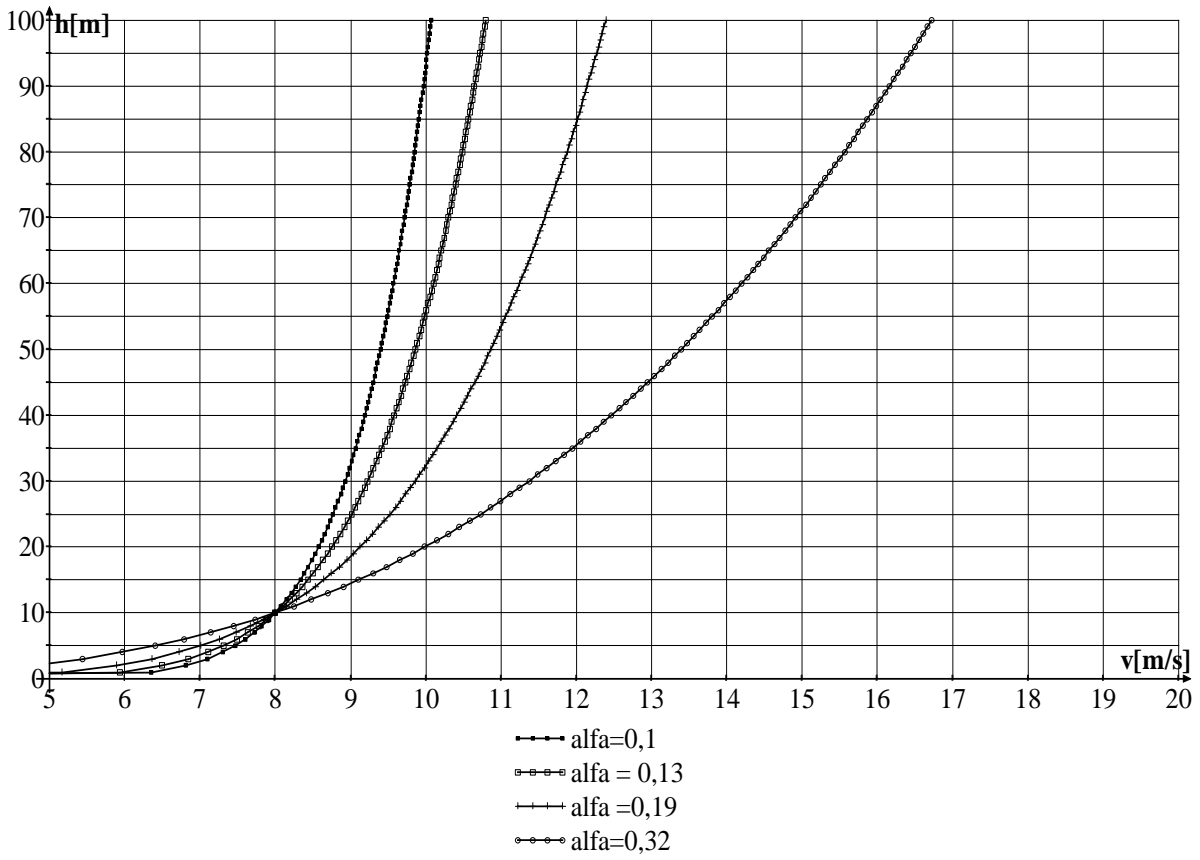

Rys. 1. Rozkład prędkości wiatru w funkcji wysokości h dla różnych współczynników chropowatości terenu

Fig. 1. Wind velocity distribution as a function of height $\mathrm{h}$ for a variety of terrain roughness coefficients

Dokonano trzech eksperymentów symulując warstwę roślinności za pomocą drucianej siatki ogrodowej, wyciorów do fajek oraz płyty piankowej (rys.3).

Inne podejście do tworzenia profili prędkości wiatru w tunelach aerodynamicznych zaprezentowano w pracach $[9,10]$. W ramach badań erozji wiatrowej gleb zaprojektowano i zbudowano przenośny tunel aerodynamiczny. Maksymalna uzyskiwana prędkość w tym tunelu to $18,7 \mathrm{~m} / \mathrm{s}$. Do wytworzenia profilu prędkości w tym tunelu wykorzystano płyty przekładkowe o strukturze plastra miodu, wykonanej z folii aluminiowej (rys.4).

Badania modelowe profile prędkości pod kątem energetyki wiatrowej prezentowali Chamoto i Agel w [4,5]. Badane były małe trójłopatowe turbiny wiatrowe. Prędkość wiatru mierzona była wzdłuż średnicy wirnika anemometrami rozmieszczonymi na różnych wysokościach z krokiem $10 \mathrm{~mm}$. 


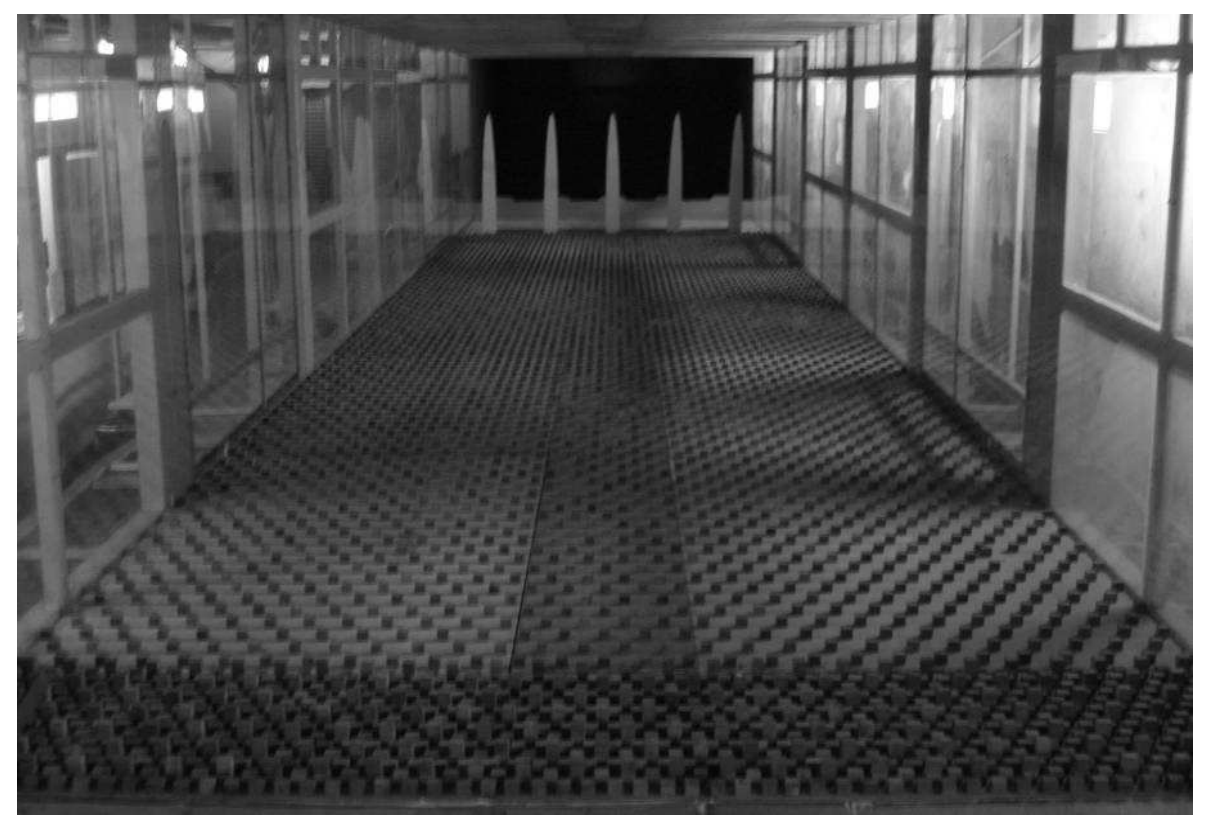

Rys.2. Widok odcinka formującego przepływ w tunelu, pracowano na podstawie [6]

Fig.2. View of the section forming the flow in the tunnel, on the basis of [6]

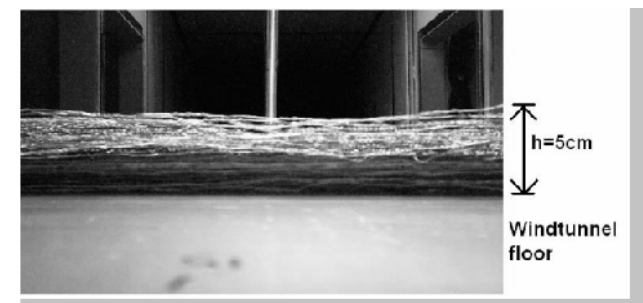

a)

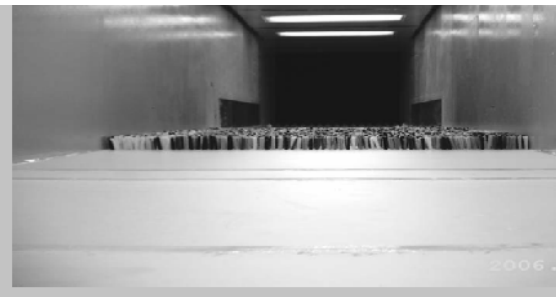

b)

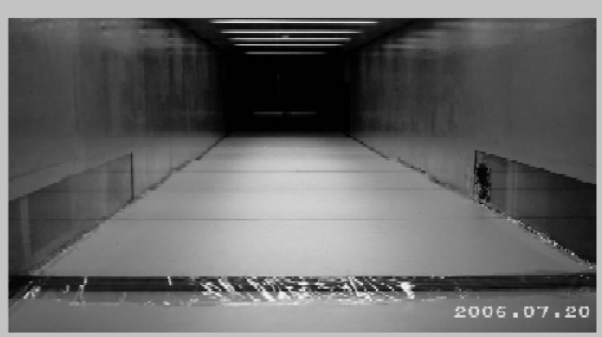

c)

Rys.3 Przykład modelowania terenu zalesionego z wykorzystaniem (a) metalowej siatki, (b) wyciorów do fajek oraz (c) płyty piankowej, opracowano na podstawie [11,12]

Fig.3. Wind tunnel test section with (a)canopy made of pipe cleaners (b) chicken wire mesh (c) foam boards looking downstream, on the basis of [11,12] 

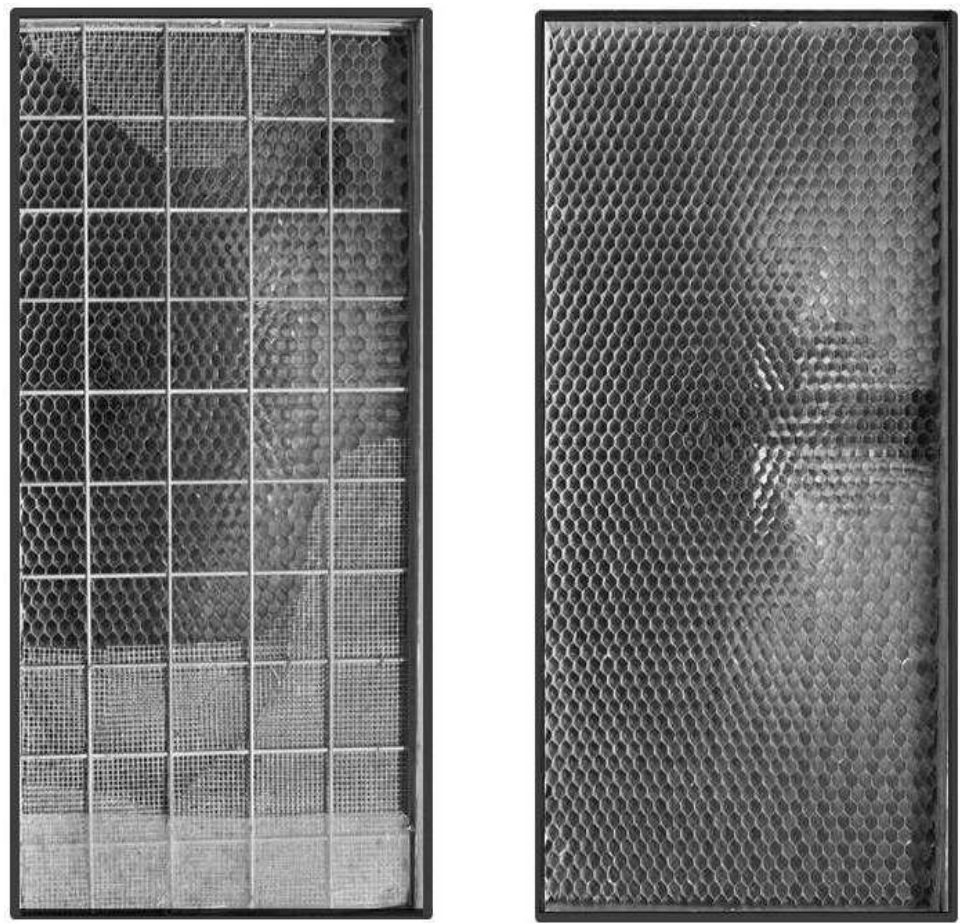

Rys.4. Warstwy ekranów użyte w celu wyrównania przepływu i utworzenia logarytmicznego profilu prędkości wiatru w tunelu aerodynamicznym, opracowano na podstawie [9]

Fig.4. The screen layers used to even the flow and create a logarithmic wind speed profile in the wind tunel, on the basis of [9]

\section{Opis stanowiska pomiarowego do badania profilu prędkości wiatru}

Badania doświadczalne mające na celu symulację profilu prędkości wiatru zostały przeprowadzone w tunelu aerodynamicznym Laboratorium Aerodynamiki Katedry Termodynamiki i Mechaniki Płynów Politechniki Rzeszowskiej. Tunel TA-1000 jest konstrukcją o obiegu otwartym ze strugą swobodną małej turbulencji, o maksymalnej prędkości przepływu w przestrzeni pomiarowej równej $45 \mathrm{~m} / \mathrm{s}$ [13].

Kontrakcja konfuzora wynosi 1:9 $\left(\phi D_{w e}=3 \mathrm{~m}, \phi D_{w y}=1 \mathrm{~m}\right)$. Średnica otwartej przestrzeni pomiarowej wynosi $\mathrm{D}=1000 \mathrm{~mm}$. Przestrzeń pomiarowa znajduje się w tzw. komorze Eiffela o konstrukcji drewnianej (sklejka) na szkielecie z rur stalowych.

Komora ma kształt sześcianu o boku ok. 3000 mm (rys.6). Do przemieszczania sond pomiarowych różnych typów przeznaczony jest trójwspółrzędny manipulator. 

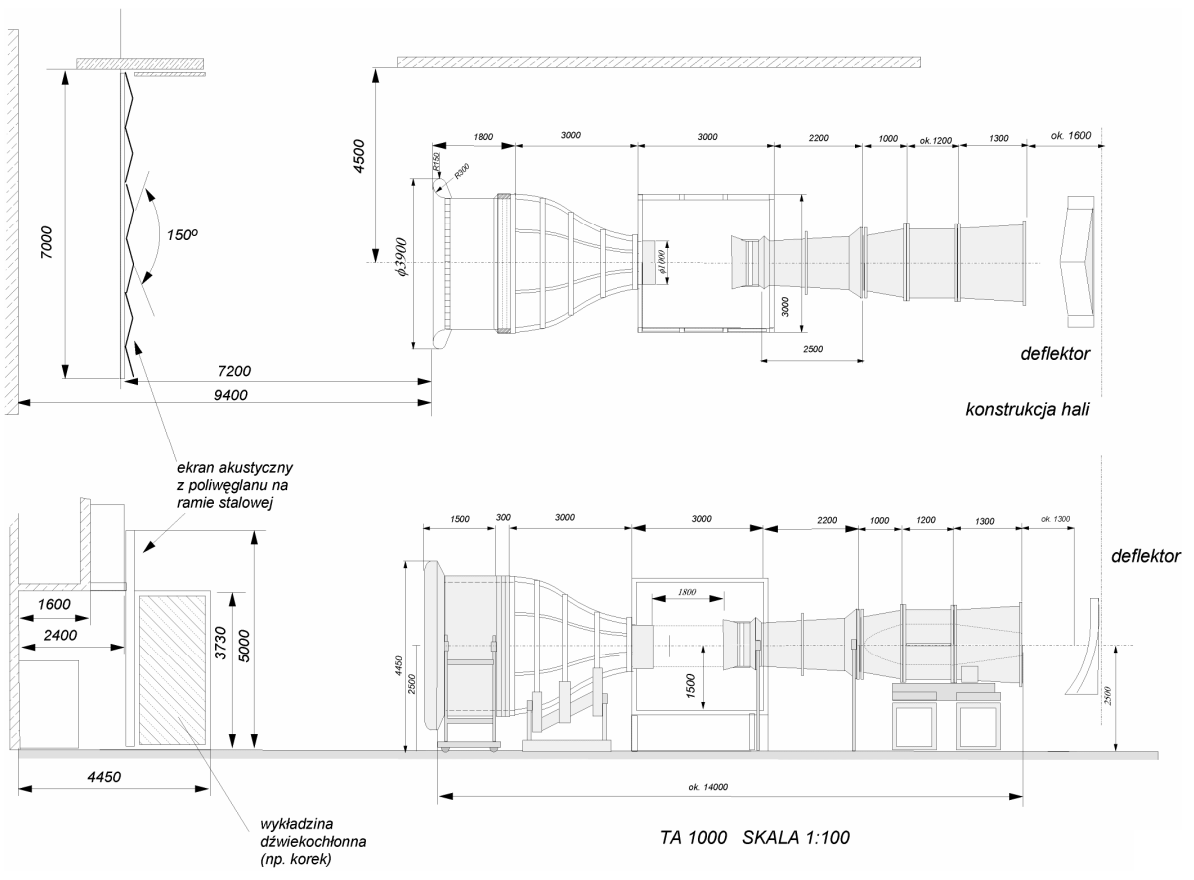

Rys._5. Schemat tunelu aerodynamicznego TA1000, opracowano na podstawie [14]

Fig. 5. Wind tunnel TA-100. Schematic, on the basis of [14]

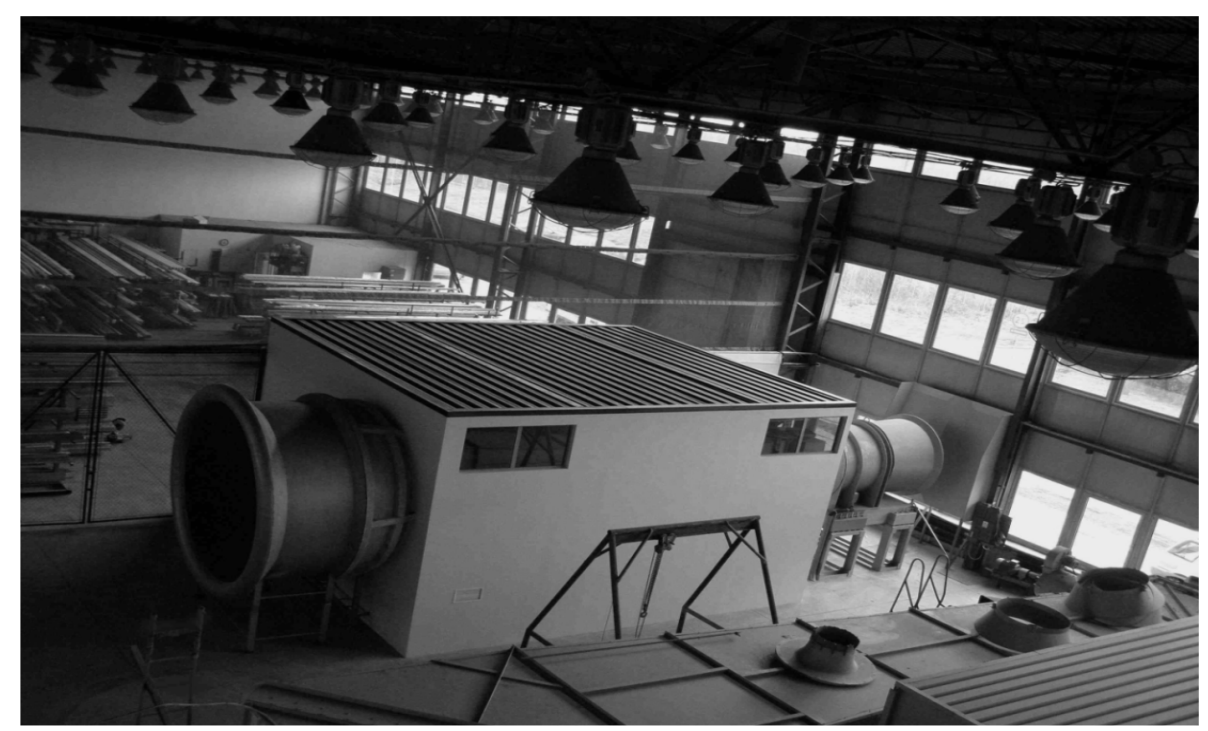

Rys. 6. Ogólny widok tunelu TA1000

Fig. 6. General view of wind tunnel TA1000 


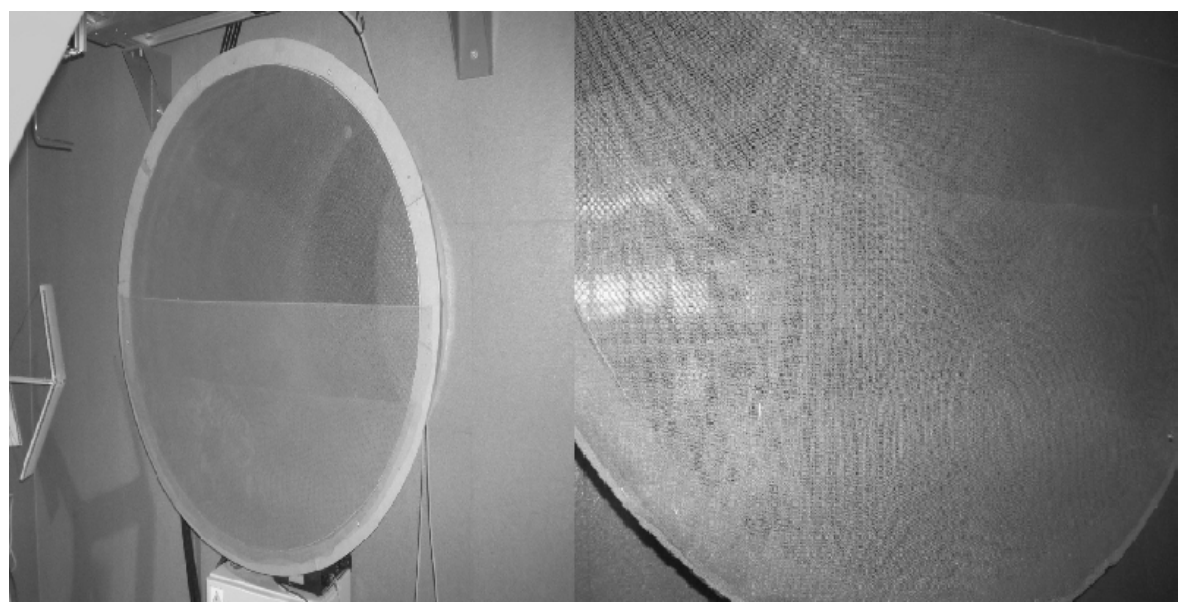

Rys.7. Siatki przysłaniające (trzy i cztery warstwy przysłaniające)

Fig.7. Obscuring grid (three and four layers of obscuring)

Pionowy profil prędkości został uzyskany za pomocą siatek przysłaniających nakładanych na przekrój wylotowy konfuzora.

Badania były przeprowadzone dla wszystkich możliwych konfiguracji siatek, tzn. z jedną, dwiema, trzema i czterema siatkami przysłaniającymi. Dla każdej kombinacji pomiary wykonane zostały dla ośmiu wartości prędkości przepływu tj.:2,5 m/s, $5 \mathrm{~m} / \mathrm{s}, 7,5 \mathrm{~m} / \mathrm{s}, 10 \mathrm{~m} / \mathrm{s}, 12,5 \mathrm{~m} / \mathrm{s}, 15 \mathrm{~m} / \mathrm{s}, 17 \mathrm{~m} / \mathrm{s}$ oraz $20 \mathrm{~m} / \mathrm{s}$. Wartości prędkości odczytywane były dla przemieszczeń pionowych sondy pomiarowej z krokiem $\Delta \mathrm{z}=20 \mathrm{~mm}$.

\section{Aparatura pomiarowa}

Do celów obsługi eksperymentu pomiaru skofigurowany został modułowy system pomiarowy złożony z modułu głównego DaqBook 2001 oraz modułów rozszerzeń DBK 41 oraz DBK 80. Przyjęta częstotliwość próbkowania wynosiła $10 \mathrm{kHz}$

System akwizycji danych obsługiwany jest przez program pomiarowy DasyLab v.11.

Sygnały elektryczne z czujników pomiarowych doprowadzone są do karty wejściowej systemu DBK80. Dla potrzeb eksperymentu wykorzystane są 4 wejścia:

0 - wejście dla sygnału ciśnienia dynamicznego mierzonego czujnikiem piezorezystywnym połączonego z sond a Prandtla.

Pozostałe wejścia są dla parametrów ośrodka w komorze Eiffela, odpowiednio: dla temperatury wejście 1 , dla ciśnienia atmosferycznego wejście 2 oraz dla wilgotności powietrza wejście 3 . Dane z wejść 1,2 i 3 kierowane są do procedu- 
ry „Atmosfera”, który wyznacza rzeczywistą gęstość powietrza w przestrzeni pomiarowej.

W module „Obliczanie W" następuje obliczenie prędkości na podstawie ciśnienia dynamicznego, i gęstości ośrodka wyznaczonego w module „Atmosfera”

Chwilowe wartości i trendy zmian ciśnienia dynamicznego można obserwować na bieżąco przy pomocy oscyloskopu wirtualnego "oscyloskop". Sygnał jest poddawany na bieżąco analizie fourierowskiej za pomocą modułu „FFT”. Wynikiem są wartości częstotliwości harmonicznych zmian ciśnienia dynamicznego.

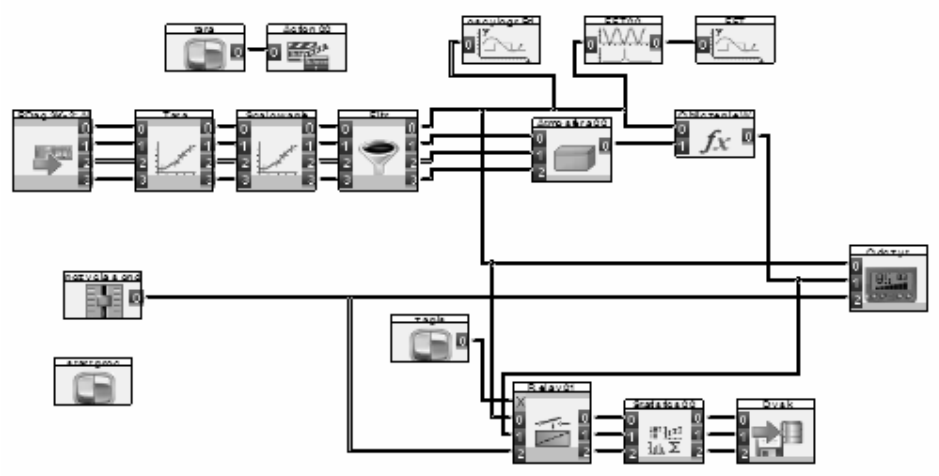

Rys. 8. Diagram pomiarowy w DasyLab

Fig. 8. The diagram in the DasyLab

Obliczona prędkość i ciśnienie dynamiczne przekazywane są do modułu sterującego zapisem „Reay01”, a następnie wykonywana jest redukcja danych z pomocą modułu statystycznego „Statistic”.

Moduł „Tara” służy do zerowania wielkości początkowych. Moduł „Filtracja” jest modułem, w którym następuje odcięcie składowych wysokich częstotliwości, wyeliminowanie szumów własnych karty pomiarowej oraz przetworników i zakłóceń zewnętrznych. Moduł „Odczyt” to narzędzie wirtualne, które jednocześnie może pełnić funkcję modułu statystycznego. Pozwala on na odczyt wielkości średnich mierzonych wartości.

Po filtracji, sygnał przekazywany do układu przekaźnikowego (wartość ciśnienia, prędkości i położenia). Moduł „Zapis” steruje momentem aktywacji przekaźnika, który generuje do ustalonej wartości związanych z zapisem, aby uzyskać rejestrację w zadanym momencie (dla warunków ustalonych). Liczebność próbki została ustalona na $1024\left(2^{10}\right)$ punktów. W module statystycznym następuje wyznaczenie wartości średniej i innych parametrów statystycznych mierzonego sygnału. 


\section{Wyniki eksperymentu}

Otrzymane wyniki pomiarowe przedstawiono w formie wykresów na rys. 9, rys.10, rys.11 oraz rys.12. Widzimy na zależności prędkości napływu powietrza w funkcji wysokości, przy różnej kombinacji siatek. Do obliczeń projektowych wybrano sytuacje z czterema siatkami i na jej podstawie stworzono profil prędkości wiatru, który został przedstawiony na rys.13. Przedstawia on zależność dla wielkości bezwymiarowych. Na osi poziomej znajduje się stosunek wysokości do planowanej wysokości osi wirnika badanej turbiny, natomiast na osi pionowej znajduje się stosunek prędkości przepływu do planowanej prędkości przepływu w osi wirnika. W związku z potęgowym charakterem funkcji podającej rozkład prędkości w obszarze wartości warstwy przyziemnej (wzór (1)), dane eksperymentalne przedstawiające rozkład prędkości napływu, gdy na wylocie konfuzora założono 4 siatki aproksymowane zostały metoda najmniejszych kwadratów za pomocą funkcji potęgowej o równaniu, gdzie argumenty i wartości zostały podane w postaci bezwymiarowej

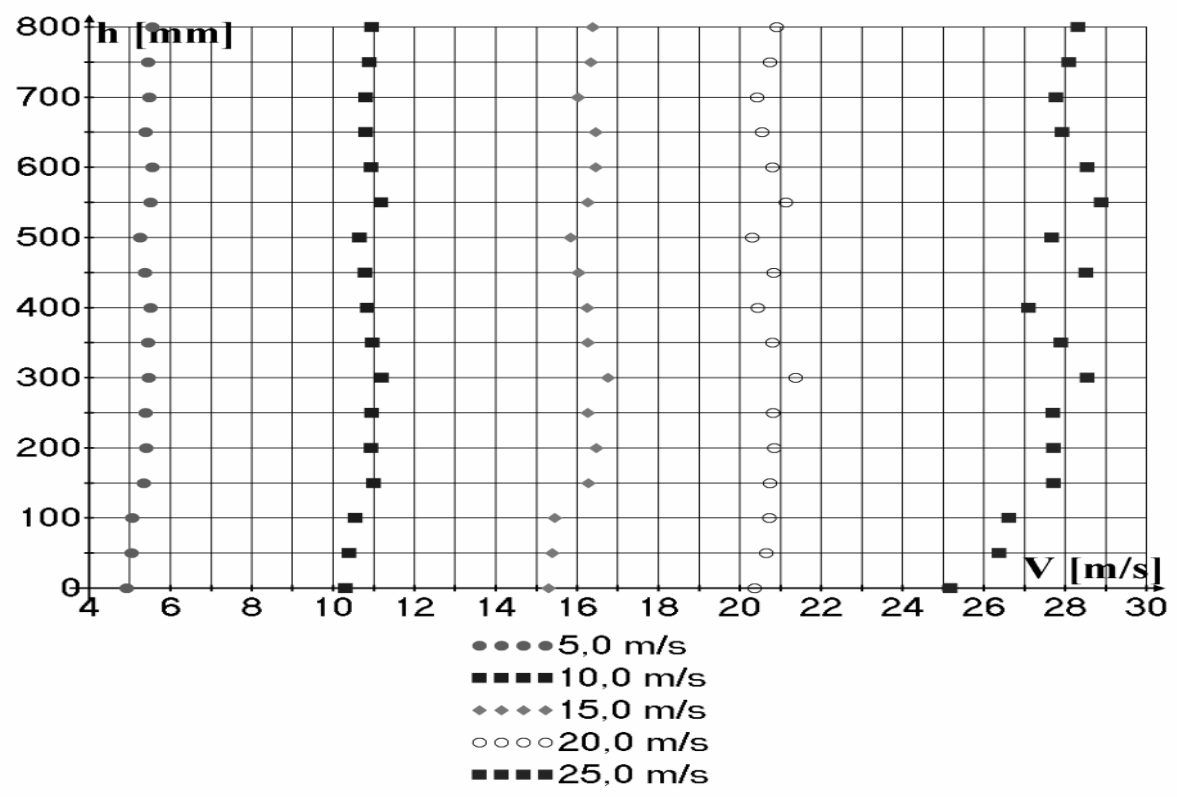

Rys. 9. Profile wiatru jednej siatki przysłaniającej w zależności od osiowej prędkości napływu

Fig. 9. Wind profile for the one flow-dumping grid depending on the axial flow velocity 


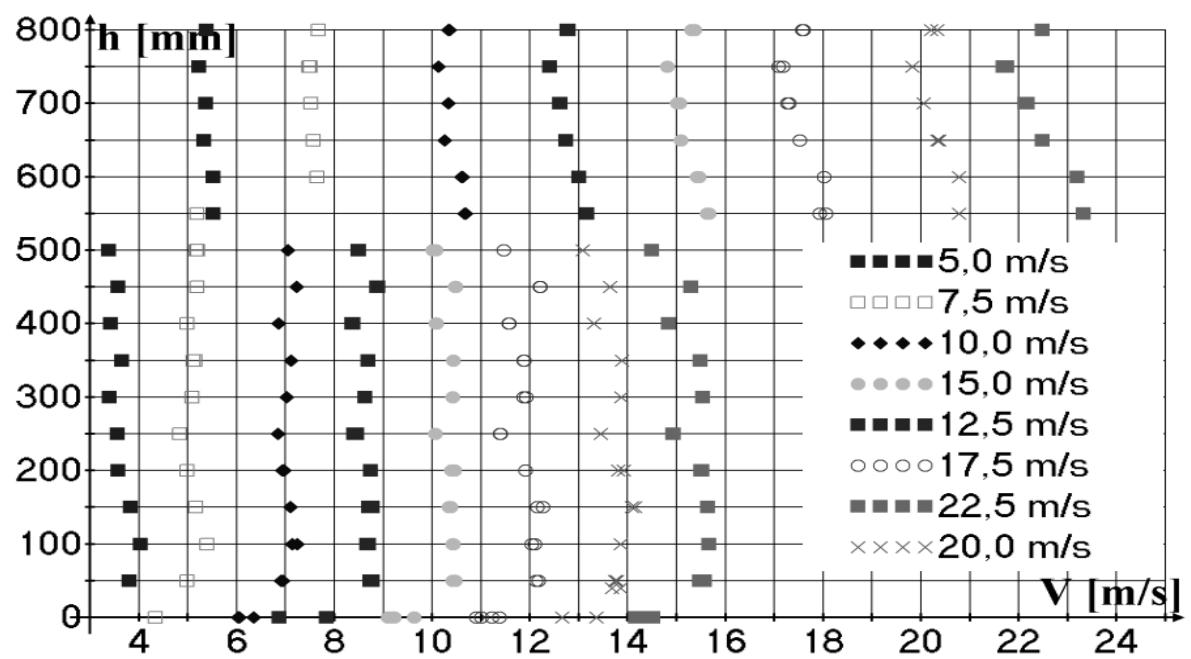

Rys. 10. Profile wiatru dla dwóch siatek przysłaniających w zależności od osiowej prędkości napływu

Fig. 10. Wind profile for the two flow-dumping grid depending on the axial flow velocity

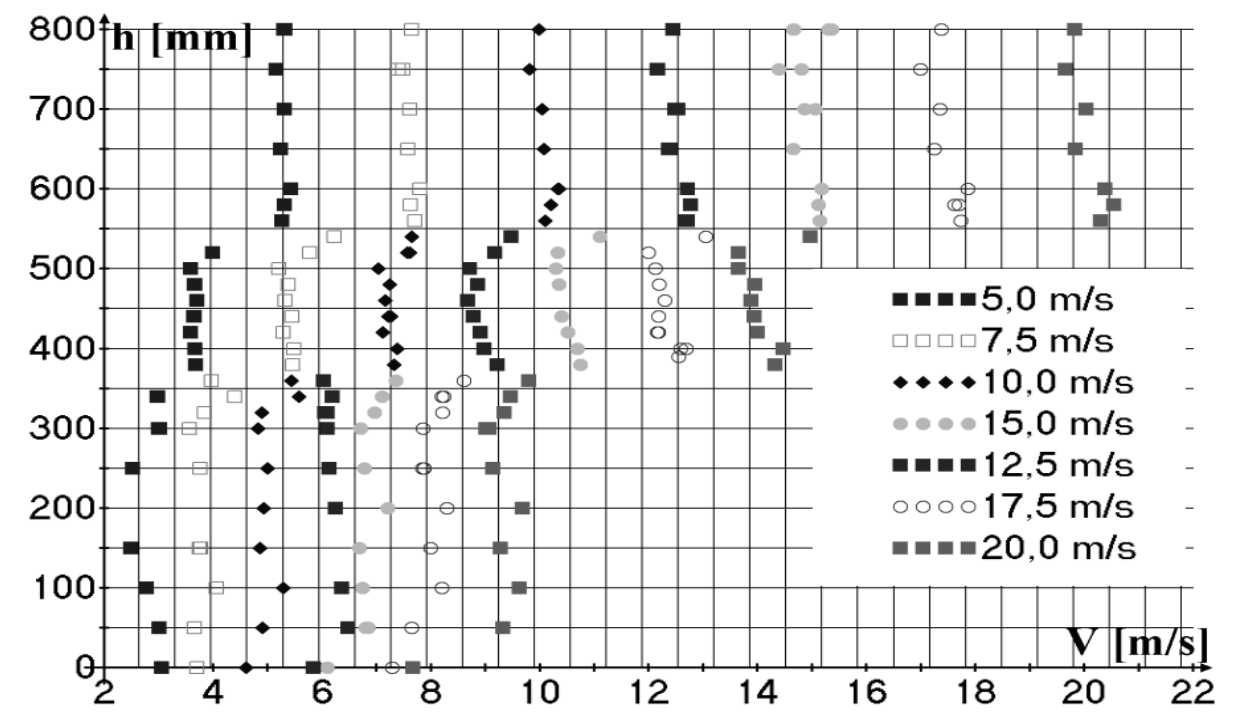

Rys. 11. Profile prędkości wiatru dla trzech siatek przysłaniających w zależności od osiowej prędkości napływu

Fig. 11. Wind profile for the three flow-dumping grid depending on the axial flow velocity 


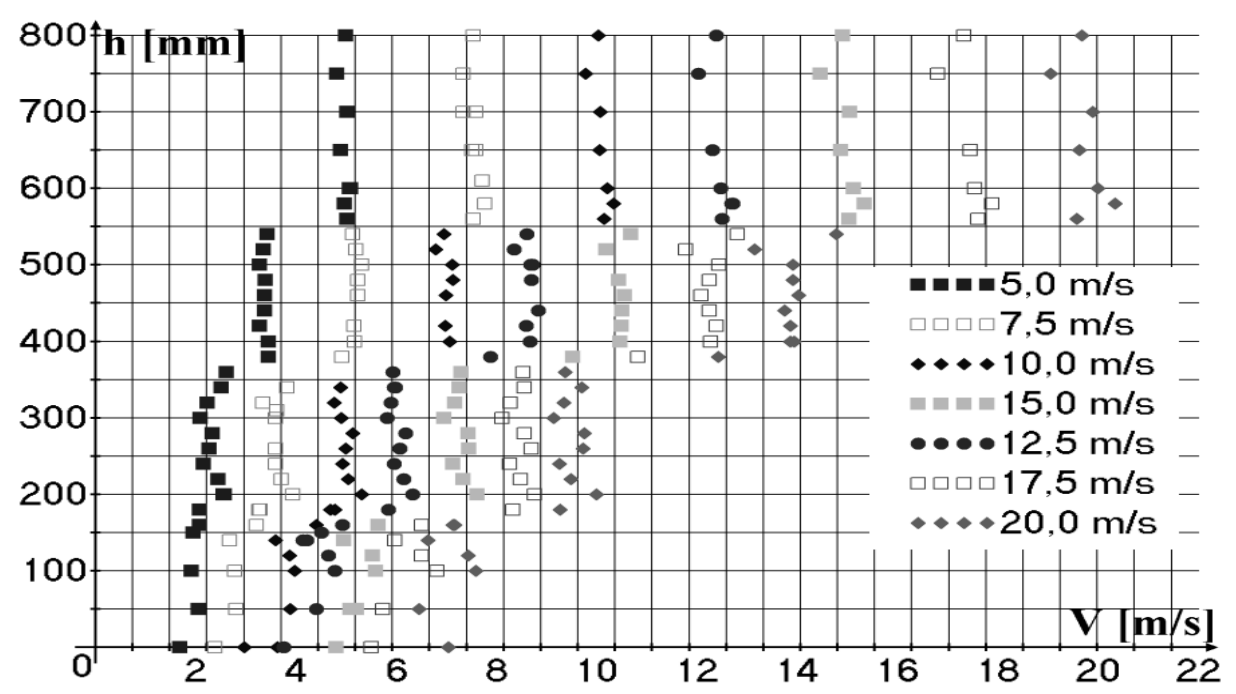

Rys. 12. Profile prędkości wiatru dla czterech siatek przysłaniających w zależności od osiowej prędkości napływu

Fig. 12. Wind profile for the four flow-dumping grid depending on the axial flow velocity

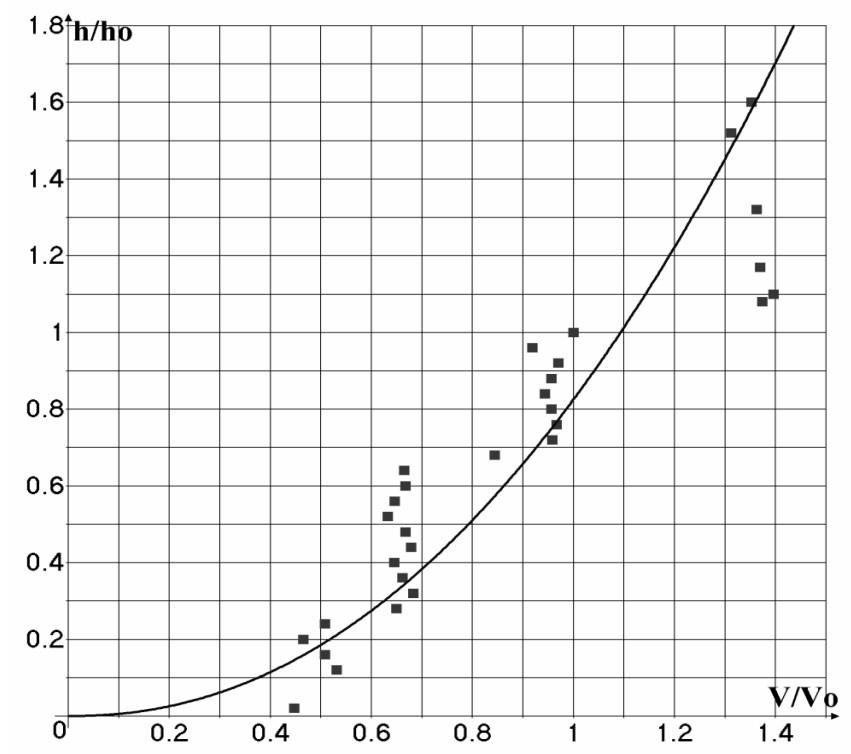

Rys. 13. Uśredniony pionowy profil prędkości wiatru opracowany na podstawie danych doświadczalnych dla układu czterech siatek

Fig. 13. Averaged vertical wind speed profile developed on the basis of experimental data for the four grids 
Na Rys. 9 widoczny jest wyrównany profil prędkości generowany przez pojedynczą siatkę. Zaskakujący jest fakt, że kształt profilu prędkości ulega pogorszeniu przy prędkości ok. $25 \mathrm{~m} / \mathrm{s}$. Być może jest to związane z wpadaniem siatki w drgania przy większych wartościach ciśnienia dynamicznego Profile prędkości przedstawione na Rys. 10 i 11 uzyskane dla dwóch i trzech siatek są dalece niesatysfakcjonujące. Akceptowalna postać pionowego rozkładu prędkości uzyskana została dla czterech siatek przesłaniających wylot z konfuzora, Rys. 13. Ten rozkład prędkości, dla czterech siatek najbardziej zbliżony jest do rzeczywistego charakteru rozkładu prędkości wiatru w warstwie przyziemnej opisanego za pomocą wzoru potęgowego ze parametrem $\alpha$, który nosi nazwę wykładnika Hellmana (wzór 1).

\section{Wnioski i uwagi końcowe}

$\mathrm{W}$ pracy przedstawiono próbę modelowania doświadczalnego pionowego profilu prędkości do wykorzystania przy badaniach modelowych wirników turbin wiatrowych.

Należy tu zaznaczyć, że w przypadku wirnika turbiny wiatrowej nie jest konieczne odwzorowanie całego profilu, tj. od poziomu gruntu, a jedynie poprawne odtworzenie rozkładu prędkości w obszarze kręgu roboczego. Stąd pokuszono się o przeprowadzenie badań w tunelu z okrągłą przestrzenią pomiarową.

W celu uzyskania niejednorodnego profilu prędkości zastosowano warstwowy układ siatek.

Akceptowalne wyniki rozkładów prędkości uzyskano dla układu czterech siatek (Rys. 12), chociaż dla lepszego odwzorowania prędkości przydałby się dłuższy odcinek swobodny za układem siatek niż pozwala na to długość przestrzeni pomiarowej $(1800 \mathrm{~mm})$.

Udało się potwierdzić, że można uzyskać rozkład prędkości zbliżony do występującego w neutralnej warstwie przyziemnej przy wykorzystaniu otwartej przestrzeni pomiarowej.

Zaletą przyjętej konfiguracji jest stałość ciśnienia wzdłuż kierunku przepływu, analogicznie jak w warstwie przyziemnej. Przyjęte rozwiązanie pozwala uprościć procedur w odróżnieniu od tuneli aerodynamicznych z zamkniętą przestrzenią pomiarową gdzie trzeba przy pomiarach sił (np. uwzględniać korektę ze względu poziomą składową gradientu ciśnienia.

\section{Literatura}

[1] Anwar M.P.: Laser positioning measurement system for Wind Tunnel Studies of structures, National Universityof Sigapore, 2005, (praca doktorska), http://scholarbank.nus.edu.sg/, [dostęp 30.04.2015 r.].

[2] Balendra T., Shah D.A., Tey K.L., Kong S.K.: Evaluation of flow characteristics in the NUS-HDB wind tunnel, Journal of Wind Engineering and Industrial Aerodynamics, 90 (2002), p. 124-133. 
[3] Burton W.V.: Wind Tunnel Simulation of an Atmosperic Boundary Layer, 2001, (praca doktorska), https://repositories.tdl.org/ttu-ir/bitstream/handle/ 2346/20785/ 31295017224139.pdf?sequence $=1$, [dostęp 30.04.2015 r.].

[4] Chamorro L.: Port'e-Agel, F. Effects of thermal stability and incoming boundarylayer flow characteristics on wind-turbine wakes: A wind-tunnel study. Bound. Layer Meteorol, 136/2010, p. 304-322.

[5] Chamorro L.P., Port'e-Agel F.: A wind-tunnel investigation of wind-turbine wakes: Boundary-layer turbulence effects." Bound. Layer Meteorol. 132/2009, p. 156-171.

[6] Counihan J.: An Improved Method of Simulation an Atmospheric Boundary Layer In a Wind tunel, Atmospheric Environment, 3/1969, p. 65-78.

[7] Gumuła S., Knap T., Strzelczyk P., Szczerba Z.: Energetyka wiatrowa., AGH Uczelniane wydawnictwo Naukowo - Techniczne, Kraków 2006.

[8] Kalda G.: Perspetywy rozwoju energetyki wiatrowej w Polsce do 2020 roku, Czasopismo Inżynierii Lądowej, Środowiska i Architektury, JCEEA t. XXX, z. 60(4/13), s. 124-138.

[9] Pelt van R.S., Zobeck T.M. Baddock M. Cox J.: Desing, Construction, and Calibration of the Portable Boundary Layer Wind Tunnel for Field Use, Transactions of the ASAE 2010, 53(3), p. 1413-1422.

[10] Pelt van R.S., Zobeck T.M.: Portable wind tunnels for field testing of soils and natural surfaces. In: Ahmed, N.A., editor. Wind Tunnel Designs and Their Diverse Engineering Applications. Rijeka, Kroatia:InTech, 2013.

[11] Perez A.L.S., Jaster D.A., Thill J., Porte-Agel F.: Wind velocity profiles and shear stresses downwind from canopy: Experiments In a wind tunel, University of Minnesota 2007, Project Raport No 492.

[12] Perez A.L.S., Jaster D.A., Thill J., Porte-Agel F.: Wind velocity profiles and shear stresses downwind from canopy: Interpretation of Tyree experiments In a wind tunnel, University of Minnesota 2007, Project Raport No 493.

[13] Szczerba Z., Mazur D.: Badanie wstępne turbiny wiatrowej w konfiguracji pionowej w tunelu aerodynamicznym oraz obliczenia przy pomocy DSM, Przegląd elektrotechniczny, 1/2014, s. 98-113.

[14] Strzelczyk P., Szczerba Z., Węsierski Ł.: Tunel aerodynamiczny do badań śmigieł i turbin wiatrowych, Pneumatyka, 1/2007, s. 1-14.

\section{MODELING VERTICAL WIND SPEED PROFILE OF IN THE WIND TUNNEL}

\section{S u m m a r y}

Wind turbines have an increasing part in producing electric energy in Poland. It means that the importance of wind farms is growing. New wind turbines are built and designing of wind turbines is acquiring more importance as well as the quality of the electric current they produce. It is becoming increasingly important to further define the factors affecting the conversion of wind energy into electricity and thus the energy system. One of the most important conditions that must be met in order to build a profitable backyard wind farm is its localization.

Speed of the wind increases with height. The height on which the rotor axis is located also affects the production of the electric energy. It seems reasonable to take into account impact the vertical profile of wind speed on the geometry of the rotor. It should be emphasized that the verti- 
cal velocity gradient has a greater impact on the aerodynamic characteristics of the turbine, in the case of small units, which can be used in households, or when working with a distributed network. This is because the tower is relatively low so the effects on the ground level will be more important than in the case of large turbines.

This article describes an experimental attempt to recreate the vertical wind profile in laboratory conditions.

Keywords: wind turbine, wind speed profile, geometry of rotor, wind tunnel

Przestano do redakcji: $30.05 .2015 \mathrm{r}$.

Przyjęto do druku: 30.10 .2015 r.

DOI: $10.7862 /$ rb.2015.125 